P-ISSN: 2774-4574; E-ISSN: 2774-4582

TRILOGI, 2(3), September-Desember 2021 (389-400) @2021 Lembaga Penerbitan, Penelitian, dan Pengabdian kepada Masyarakat (LP3M) Universitas Nurul Jadid Paiton Probolinggo

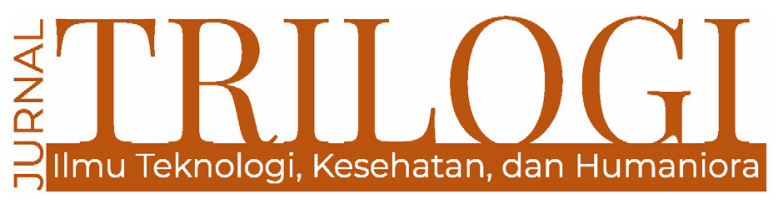

\title{
KONTRA RADIKALISME PESANTREN: MELACAK PEMIKIRAN KEBANGSAAN KIAI ZAINI MUN'IM
}

\author{
Ainul Yakin \\ Universitas Nurul Jadid \\ Hafilul Hafilul Fawaid \\ Universitas Nurul Jadid \\ Achmad Ainur Rafiq \\ Universitas Nurul Jadid \\ Faqih Thariqu Billah \\ Universitas Nurul Jadid
}

\author{
Affan A Muzakki \\ Universitas Nurul Jadid \\ R. Ach. Supandi \\ Universitas Nurul Jadid \\ Maulidi Iksan \\ Universitas Nurul Jadid
}

\begin{abstract}
Abstrak
Maraknya gerakan ektremisme dan redikalisme atas nama agama belakangan ini, serta golongan yang mempertentangkan keislaman dan kebangsaan (keindonesiaan), bahkan ada yang menghubungkan dengan pesantren, maka perlu menalaah pemikiran kebangsaan tokoh pesantren, KH. Zaini Mun'im. KH Zaini adalah pendiri pesantren Nurul Jadid Paiton Probolinggo. Kiai Zaini tidak hanya melahirkan pemikiran kislaman tapi juga kebangsaan. Perjunagan beliau terhadap tanah air tidak hanya dalam bentuk pemikiran, tapi juga dibuktikan dengan tindakan nyata dengan kegigihannya memperjuangan kemerdekaan hingga akhirnya dipenjara oleh Belanda. Artikel ini menalaah pemikiran KH. Zaini Mun'im tentang kebangsaan. Metode dalam penelitian ini adalah metode kepustakaan (library research) dengan studi analisis deskriptif. Studi analisis menggunakan analisis konten dan deskriptif terkait pemikiran kebangsaan $\mathrm{KH}$. Zaini. Hasil penelitian menunjukkan bahwa pemikiran KH. Zaini Mun'im tentang kebangsaan tertuang Trilogi santri dan Panca Kesadaran Santri yang dikenal al-dawabit al-santri dan al-wa'iyyah al-khamsah. Kiai Zaini tidak bertentangan dengan keislaman. Ilsam tidak perlu dipertentangkan dengan negara, keduanya adalah ranah dalam satu konsep perjuangan. Salah satu poin dalam konsep Panca Kesadaran Santri adalah kesadaran berbangsa dan bernegara. Ideologi yang ditanamkan Kiai Zaini kepada santrinya tersebut dikaji tidak hanya pada tataran ideologis saja, tapi juga pada tataran praktis. Pemikiran Kebangsaan KH. Zaini Mun'im bercorak Islam tradisional yang berfokus pada bidang akhlak tasawwuf, akidah (ahlussunah wal jama'ah) dan fiqh. Sedangkan, pemikiran kebangsaannya digunakan sebagai perjuangan untuk mempersatukan umat dan melakukan perlawanan terhadap penjajah dalam memperjuangkan kemerdekaan Indonesia.
\end{abstract}

Kata Kunci: KH. Zaini, Kebangsaan, Radikaslime dan Ideologi. 


\section{A. Pendahuluan}

Belakangan, gelombang gerakan Islam di Indoensia mengalami pergerakan yang cukup dinamis, mulai dari gerakan muderasi, liberalisasi sampai formalisasi Islam, termasuk gerakan radicalism agama. Gerakan tersebut telah menguras energi masyarakat dan kalangan pemerintah. Sementara itu gerakan yang cukup mengancam terhadap keutuhan bangsa adalah gerakan Islam yang membenturkan antara Negara dengan Islam. Islam dipandang sebagai entitas yang bediri sendiri yang tidak bisa disatukan dengan Negara. Seiring terjadinya refromasi tahun 1998, dengan dibukanya kran demokrasi, peruabahan-perubahan mendasar berjalan sangat cepat dan penuh gejolak, baik dari segi ekonomi, politik dan budaya termasuk di dalamnya agama, terurama pada saat pademi seperti sekarang ini. Problem-problem yang ada seperti pengelolaan keuangan Negara, korupsi yang sistemik, silang sengkerut tata niaga produk pertanian, cacat UU/RUU yang berkaitan dengan hajat hidup orang banyak. ${ }^{1}$ Perubahan tersebut setidaknya telah berkonstribusi munculnya gerakan-gerakan ekstremisme dan rasdikalisme atas nama agama.

Gelombang gerakan tersebut, jika tidak dibendung baik melalui pemikiran maupun tidakan yang lebih konkret, problem di atas menjadi ancaman tersendiri bagi keutuhan bangsa. Berbagai macam gerakan yang selalu membenturkan antara agama dengan Negara tersebut sejatinya bertentangan dengan nilainilai agama itu sendiri, para ulama dan founding father bangsa. Sementara pada sisi lain, para pendahulu bangsa dari kalangan ulama' tidak mempermasalahkan hubungan antara agama dan Negara. Bahkan menurut mereka keduanya saling melengkapi demi keberlangsungan agama dan Negara. Disinilah kemudian menjadi penting mengungkapkan pemikiran kebangsaan para ulama nusantara, salah satunya KH. Zaini Mun'im, seorang ulama' dan pejuang dari keturunan orang alim, ulama, bangsawan Madura, yang dilahirkan pada tahun 1906 di Pamekasan Madura. Beliau menghabiskan masa kecil sampai dewasa belajar ilmu agama. Hingga akhirnyan beliau mendirikan pesantren di Paiton, Probolinggo, Jawa Timur. ${ }^{2}$ Kiai Zaini tidak hanya bergerak melawan penjajah Belanda secara nyata di lapangan, tapi yang tidak kalah pentingnya juga adalah pemikiran

1 Suib, M. Syaiful. "Islam dan Indonesia Menurut KH Zaini Mun'im: Wawasan Tentang Islam Nusantara." AT-TURAS: Jurnal Studi Keislaman 5.2 (2018): 245-265.

2 Suib, Islam, 245-265. kebangsaannya yang mengilhami masyarakat untuk cinta dan berjuang membela bangsa dan Negara.

\section{B. Metode}

Penelitian ini merupakan penelitian kepustakaan (library research), penelitian yang menggunakan data dan informasi dengan bantuan berbagai macam materi yang bersumber dari buku-buku, majalah, naskah-naskah, catatan, kisah sejarah, dokumen-dokumen, serta data wawancara untuk memperkuat data kepustakaan dari sumber sekunder. Pengumpulan data penulis menggunakan metode kualitatif sebagai prosedur penelitian yang dapat menghasilkan data deskripsif berupa kata-kata tertulis dari objek penelitian. Penulis membagi sumber data menjadi dua bagian, yaitu data primer dan sekunder. Sumber data primer meliputi karya Kiai Zaini seprerti Tafsirul Qur'an Bil Imla', Nazhmu Syu'abil Iman, Tafsir surat al-Fatihah dan Tulsian tentang Beberapa problematika dakwah Islamiyyah.

Sedangkan data sekunder adalah tulisan peneliti tentang Kiai Zaini seperti karya M Masyhur Amin, M Nasikh Ridwan berjudul KH Zaini Mun'im (Pengabdian dan Karya Tulisnya), Qanun Asasi PP. Nurul Jadid serta sejumlah informan yang menjadi santri dan menyaksikan langsung masa hidup kiai Zaini. Data tersebut menajdi pijakan dan tolak ukur dalam menganalisis gagasan dan pemikiran beliau atau review telaah terhadap karya yang dihasilkannya tentang pemikiran kebangsaan.

Pengolahan data dalam penelitian ini menggunakan metode deskriptif analitis. Penulis berusaha mendiskripsikan secara sistematis gagasan dan pemikiran KH Zaini Mun'im tentang pemikiran kebangsaan. Kemudian penulis mencoba menganalisis pemikirannya baik dalam kerangka teoretis atau dimensi praktis. Fungsi analisis ini berupaya untuk menyingkap pemikiran beliau di balik peran-perannya sebagai instrumen-instrumen pendukung, sehingga diketahui lebih detail kepentingan-kepentingan yang menyertai pemikiran dan gagasan beliau. ${ }^{3}$ Sebagai alat analisis data (tool of analysis), penulis memakai hermeneutika sosial, ini dimaksudkan untuk menganalisis secara jernih makna yang terkandung dalam keseluruhan gagasan dan pemikiran Kiai Zaini tentang kebangsaan.

3 Ismail Nawawi, Metode Penelitian Kualitatif, Sidoarjo, Dwiputra Pustaka Jaya, (2012), h. 261 


\section{Islam dan Kebangsaan}

Islam tidak hanya mengajarkan urusan ibadah ritual (ukhrawi) yang berhubungan dengan Tuhan yang disebut iabdah mahdhah saja. Islam juga mengatur urusan keduniaan atau hubungan dengan manusia yang dikenal dengan ibadah muamalah, seperti urusan ekonomi, politik, pemerintahan dan sebagainya. Urusan politik salah satunya membahas tentang masalah kebangsaan. Kebangsaan bisa menjamin kehidupan yang rukun dan damai dalam perbedaan. Kerukunan dan perdamaian membuat ajaran agama bisa lebih mudah dipahami, dihayati dan diamalkan. Maka dari itu, mau tidak mau kehidupan berbangsa dan bernegara menjadi prasyarat agar ajaran Islam bisa terlaksana dengan baik. Sebab melaksanakan ajaran Islam adalah kewajiban bagi umat Islam. Jadi, menyediakan berbagai persyaratan bagi tegaknya ajaran Islam pun menjadi hal yang wajib. Sampai di sini kita bisa dapat meyatakan bahwa memperjuangkan nilia-nilai kebangsaan menjadi wajib hukumnya. ${ }^{4}$

Secara alamiah manusia terlahir dalam keadaan berbeda-beda baik berbeda dalam suku, bangsa dan golongan dan ras. Perbedaan tersebut bukan untuk dijadikan alat untuk saling bermusuhan karean perbedaan suku dan ras, dan bukan sebagai penanda bahwa satu golongan lebih tinggi dari para yang lain. Akan tetapi perbedaan tersebut dijadikan dijadikan media untuk saling melengkapi antara satu dengan yang lain. Sehingga kehidupan berngsa untuk mencapai kesatuan ada sebuah dalam perbedaan adalah suatu keniscayaan. Sebab yang paling mulia di antara golongan yang berbeda tersebut adalah orang yang paling bertaqwa kepada Allah. Sebagaimana firman Allah dalam Al-Quran AlHujarat Ayat 13 sebagai berikut:

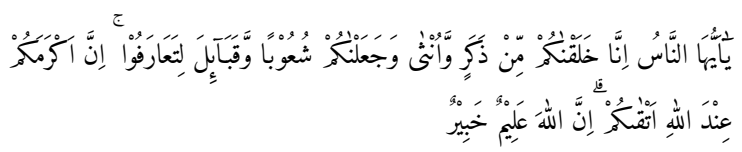

Artinya: Hai manusia, Sesungguhnya Kami menciptakan kamu dari seorang laki-laki dan seorang perempuan dan menjadikan kamu berbangsa - bangsa dan bersuku-suku supaya kamu saling kenal-mengenal. Sesungguhnya orang yang paling mulia diantara kamu disisi Allah ialah orang yang paling taqwa diantara kamu. Sesungguhnya Allah Maha mengetahui lagi Maha Mengenal. ${ }^{5}$

4 Kesimpulan tersebut bisa didasarkan pada kaidah fighiyah yang berbunyi: maa laa yatimmu al-wajibu ila bihi fahuwa waajibun yang memiliki arti bahwa sebuah kewajiban tidak akan tegak jika tidak ada sesuatu, maka sesuatu itu menjadi wajib.

5 Al-Quran: Al-Hujarat:13
Dari ayat di atas dapat dipahami bahwa Islam sangat menekankan pentingnya menegakkan nilai-nilai universal seperti nilai kebenaran, keadilan, kesetaraan, kasih sayang, kesabaran, perpaduan, kebaikan, keindahan dan sebagainya. ${ }^{6}$ Penegakan nilai-nilai tersebut tentu membutuhkan cara dan wadah yang berupa sistem pemerintahan. Sistem pemerintahan tersebut yang dikelola dalam sebuah bangsa dan Negara. Kebangsaan sejatinya merupakan proses alamiah, yang setiap orang tidak bisa terlepas dari kehidupan berbangsa dan bernegara. Sedangkan bentuk pemerintahan dalam sebuah bangsa merupakan produk ijtihad yang bisa saja secara langsung dan eksplisit tidak dijumpai di dalam ajaran Islam.

Islam memandang negara tak ubahnya semacam badan, jasad, atau raga yang berskala makro bagi jiwa kolektif manusia. Seperti raga, atau jasad manusia perorangan, di dalam badan besar negara juga terdapat nafsu yang menurut Al Quran bersifat ammarah bi al-su', tend to corrupt. Maka, sikap dasar Islam terhadap negara, bukan membenci atau mengingkari, tapi mewaspadai dan mengkritisi. Apa boleh buat tak seorang manusia bisa eksis tanpa badan. Demikian pula manusia kolektif (masyarakat), tidak bisa eksis tanpa badan bersama, yaitu pemerintahan/ negara. Namun, karena di dalam badan ada kecenderungan-kecenderungan koruptif, kesadaran manusia perlu selalu mewaspadainya; bukan sebaliknya seperti yang terjadi selama ini, di mana negara yang justru mewaspadai dan mencurigai manusia-rakyatnya. Amar makruf nahi mungkar (mendukung langkah negara yang lurus (adil) dan meluruskan yang bengkok (tidak adil) adalah prinsip umat beragama terhadap Negara.

Berangkat dari pemahaman di atas, hubungan Islam dengan kebangsaan dapat dijelaskan sebagai berikut: Pertama, kebangsaan adalah sebuah produk ijtihad. Konsep kebangsaan memang tidak secara langsung dan eksplisit dijumpai dalam ajaran Islam, tapi ada nilai-nilai universal di dalamnya yang sejalan dengan ajaran Islam. Kedua, dalam konteks Indonesia, secara historis, wawasan dan pilar-pilar kebangsaan Indonesia seperti Pancasila, UUD 1945, Bhineka Tunggal Ika dan NKRI dilahirkan oleh para pendiri bangsa (the founding father) sejalan dengan nilai-nilai Islam. Hal ini tidak heran sebab sebagian besar the founding fathers Indonesia

6 Istilah yang sepadam dengan makna kebangsaan dalam surat disinggung pada surat al-Anfal (6) ayat 41 yang menjelaskan bahwa tanah-tanah negeri yang ditaklukan oleh tentara Islam dibagikan kepada tentara yang menaklukkannya, fakir miskin, dan lain-lainnya. Muntaha Azhari, Islam Indonesia Menatap Masa Depan, P3M, Jakarta, (1989), h. 23 
adalah para ulama dan tokoh-tokoh Islam seperti K.H.Wahid Hasyim, H.Agus Salim, Muhammad Natsir, K.H. Mas Mansyur, bahkan Soekarno dan Hatta, yang tidak tergolong sebagai ulama atau ahli agama. Meski begitu, Soekarno dan Hatta adalah dua tokoh yang tergolong sebagai orang yang religius dan Islamis. Keduanya ingin sekali mengamalkan ajaran-ajaran Islam tentang kemajuan sebagaimana yang tercantum dalam al-Qur'an dan as-Sunnah.

Sejauh ini, rakyat Indonesia sudah cukup berpengalaman dalam kehidupan berbangsa dan bernegara. Sebab, bangsa Indonesia telah menampilkan suatu pola kehidupan beragama yang dituangkan dalam Garis-garis Besar Haluan Negara. Bahkan lebih dari itu, ada aset nilai-nilai agama dakam suratan konstitusi UUD 1945 yang cukup besar untuk bisa dikembangkan. Usaha para tokoh Islam di Indonesia dalam membangun pilar-pilar kebangsaan dan melaksanakannya dalam sebuah negara kesatuan Republik Indonesia, sesungguhnya mempunyai kemiripan dengan apa yang dilakukan oleh Nabi Muhammad Saw. sebagaimana yang tertuang dalam Piagam Madinah atau Mitsaq al-Madinah.

Konsep kebangsaan, sebagaimana yang telah digagas oleh para tokoh agama memperlihatkan bahwa hubungan Islam dengan negara di Indonesia tidak didasarkan pada logo, simbol, atau namanya yang bersifat formal, tapi lebih pada isi dan substansinya. Meskipun dasar kebangsaan negara Indonesia bukan syari'at Islam, tapi pilarpilar kebangsaan Indonesia yang telah terbentuk sangat menjamin, melindungi, dan menyuburkan pelaksanaan nilai-nilai ajaran Islam dalam berbagai bidang kehidupan baik dalam sosial, ekonomi, budaya, pendidikan, dakwah dan lain sebagainya.

Ketiga, secara psikologis, manusia adalah makhluk yang dalam menjaga keberlangsungan hidupnya, baik secara jasmani atau rohani, spiritual atau material yang sangat membutuhkan orang lain dan bergantung kepada orang lain. Berbagai kebutuhan hidup manusia, seperti sandang, pangan, papan, pendidikan, kesehatan, keamanan, hiburan dan lain sebagainya tidak bisa dipenuhi oleh dirinya sendiri. Seluruh kebutuhan manusia di dunia berasal dari hasil tolong menolong dan kerjasama dengan orang lain, terutama orang-orang di sekelilingnya. Secara psikologis, manusia terkadang melampaui batas, cenderung melanggar, anarkis dan lain sebagainya. Dalam mendapatkan segala kebutuhan tersebut, maka diperlukan adanya nilai-nilai dan etika yang harus dipatuhi terlebih dahulu. Agar nilai-nilai etika mampu ditegakkan, maka diperlukan adanya pemerintahan dan agar pemerintahan tersebut tidak berbuat sewenangwenang. Maka, pemerintahan pun mesti tunduk pada aturan yang lebih tinggi yang berasal dari Tuhan.

Keempat, secara pragmatis, wawasan kebangsaan sangat dibutuhkan untuk menjamin terwujudnya sebuah kehidupan yang aman, tertib dan damai. Dalam keadaan negara yang demikian, maka memungkinkan manusia bisa memenuhi berbagai kebutuhan hidupnya. Pemahaman, penghayatan dan pengamalan ajaran Islam membutuhkan sebuah wadah yakni negara yang tertib, aman dan damai, dan negara yang demikian harus memiliki wawasan kebangsaan yang kokoh. Jika telah menjalankan kehidupan kebangsaan yang telah dijelaskan di atas, maka umat Islam akan bisa menjalankan ibadahnya dengan khusyuk, melakukan kegiatan dakwah, melaksanakan pendidikan, dan melahirkan berbagai karya-karya yang inovatif lainnya. Itulah hubungan Islam dengan kebangsaan yang sudah ditanamkan sejak Indonesia berdiri. ${ }^{7}$

\section{D.Kiai Zaini: Figur Islamis-Nasionalis}

Kiai Zaini lahir pada tahun 1906 di desa Galis kecamatan Galis, sekitar 9 km sebelah timur kota Pamekasan Madura, Jawa Timur dari pasangan KH. Abdul Mun'im dan Nyai Hamidah. ${ }^{8}$ Zaini kecil ini sangat beruntung memiliki ayah

7 Terkait hal ini Allah menjelaskan dalam Al-Quran surat AlMaidah Ayat 48 yang berbunyi:

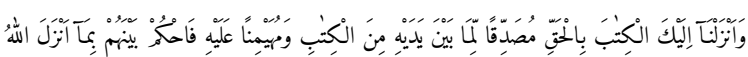

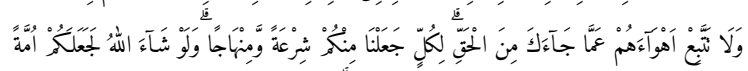

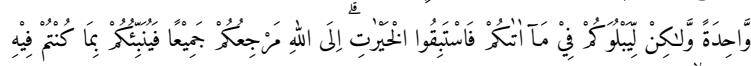

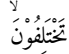

Pada ayat tersebut dijelaskan bahwa Allah menurunkan Al Quran dengan membawa kebenaran, membenarkan apa yang terkandung dalam Kitab-Kitab sebelumnya. Oleh karenanya Allah memerintahkan agar memurtuskan perkara menurut hukumhukum Allah turunkan. Karena Allah telah memberikan aturan dan jalan yang terang. Sekiranya Allah menghendaki, niscaya umat manusia dijadikan-Nya satu umat (saja), tetapi Allah hendak menguji manusia dalam perbedaan. Maka berlomba-lombalah berbuat kebajikan. Terkait dengan kebangsaan ini Allah sengaja menciptakan manusia dalam keadaan yang berbeda-beda dari segi suku, bangsa dan ras. Hal ini untuk menguji umat manusia agar berlomba-lomba dalam berbuat baik.

8 Tim, Mengenal Pondok Pesantren Nurul Jadid Paiton Probolinggo, Probolinggo: Biro Umum, (1998), h. 17. 
yang sangat peduli terhadap pendidikannya. Ayahnya memperhatikan Zaini dalam hal mengaji, menghafal al-Qur'an dan mendalami ilmu-ilmu agama dasar. Pendidikan dalam keluarganya cukup membekas dalam membentuk karakter dan kepribadiannya sehingga menjadi seorang ulama. Disamping itu, Ayah beliau, Kiai Abdul Mun'im adalah termasuk keluarga dari kalangan elit, bangsawan, yang secara nasab bersambung dengan keturunan raja-raja Sumenep. Bahkan jika ditelusuri nasabnya sampai pada Rasulullah Muhammad SAW melalui jalur Bindhârâ Sa'ûd. ${ }^{9}$ Terdapat beberapa faktor yang mempengaruhi karakter dan semangatnya dalam beragama. ${ }^{10}$ Di antaranya adalah ketekunan sang ayah dan kasih-sayang serta kecintaan dari ibunya.

Pada tahun 1917 dalam usianya yang baru menginjak usia 11 tahun, KH. Zaini masuk sekolah Volk School (Sekolah Rakyat) pada masa penjajahan Belanda. Di sekolah ini, KH. Zaini mengenyam pendidikan ala Belanda selama empat tahun dan berakhir pada tahun 1921. Di sekolah ini, KH. Zaini banyak memperoleh pengetahuan umum, membaca dan menulis, serta bahasa dan pengetahuan ala Belanda. Setelah keluar dari Sekolah Rakyat, pendidikan dilanjutkan di lembaga pendidikan non formal atau pondok pesantren. Beberapa pesantren yang telah disinggahinya adalah PP Pademangan Bangkalan Madura di bawah asuhan KH. Moh. Kholil dan KH. Muntaha selama satu tahun. Pondok Pesantren Banyuanyar Pamekasan di bawah asuhan $\mathrm{KH}$. Abdul Hamid dan KH. Abdul Madjid sejak tahun 1922. ${ }^{11}$ Pondok Pesantren Sidogiri Pasuruan di bawah asuhan KH. Nawawi sejak tahun 1925. PP Tebuireng Jombang di bawah asuhan $\mathrm{KH}$. Hasyim Asy'ari.12

Setelah melakukan pengembaraan di beberapa pesantren di tanah air, kemudian pada tahun 1928, KH. Zaini Mun'im memperdalam agama di Makkah selama lima tahun dan di Madinah selama empat bulan hingga tahun 1934 dengan beberapa guru diantaranya adalah $\mathrm{KH}$. M. Baqir, Sheikh Umar Hamdani al-Maghribi, Sheikh Alwi al-Maliki (Mufti Maliki di Makkah), Sheikh Sa'id al-Yamani dan Sheikh Umar Bayunid (keduanya adalah mufti Shafi'i di Makkah), Shaikh Yahya Sangkurat (berasal dari Malaysia) dan

9 M. Rahwini Anwar. Sejarah Almarhum KH. Zaini Mun'im dan Pesantren Nurul Jadid. PP. Nurul Jadid, (1979), h. 34.

10 Mun'im, A. Rafiq Zainul. "Konsep Mukmin dalam Tafsir AlQur'an Bi Al-Imla'Karya KH. Zaini Mun'im." (2017), h.18-31.

11 M. Masyhur Amin dan M. Nasikh Ridwan, KH. Zaini Mun'im Pengabdian dan Karya Tulisnya (Yogyakarta: LKPSM, 1996), h. 25.

12 Ibid., 27. Lihat juga Tim, Mengenal, h. 19
Shaikh Ibrahim al-Barri di Madinah.

Dari hasil didikan keluarga yang agamis dan pengembaraan ilmu pengetahuan Kiai Zaini baik di dalam Nusantara maupun luar negeri, telah banyak membentuk beliau menjadi orang alim dan punya karakter yang kokoh dalam memperjuangan Islam. Hal ini ditandai sekembalinya beliu dari Madinah ke Nusantara. Kala itu, Indnesia belum merdeka, situasi inilah juga menuntut Kiai Zaini ikut andil dalam memperjuangkan kemerdekaan bersama jaringannya yang dibangun di berbagai daerah termasuk di Jojgakarta. Pasca kemerdekaan, sekitar tahun 1947, Kiai Zaini merantau ke tanah Jawa dan menetap di pesantren Salafiyah Syafi'iyah Sukorejo. Di sana, akhirnya beliau beraktualisasi diri. Sampai akhirnya memilih tinggal desa Karanganyar Paiton Probolinggo sebagai tempat berjuang hingga mendirikan pondok pesantren yang diberi nama Pondok Pesantren Nurul Jadid. Hingga akhirnya beliau wafat pada tanggal 26 Juli 1976 M, bertepatan dengan tanggal 29 Rajab1396 H. ${ }^{13}$

Selain aktif dalam perjuangan, Kiai Zaini juga aktif menulis karya-karya ilmu keislaman seperti Nadzmu Safinatun Najah pada tahun 1957, Nadzmu Syu'abi al-Iman pada tahun 1967, Tafsir al-Qur'an bi al-Imla' pada tahun 1973, Taysirul Ushul fi IImil Ushul, Tafsirul Qur'an Bil Imla'.14 Dari sejumlah karya tersebut, menunjukkan bahwa beliau memiliki wawasan keislaman yang kuat dalam bidang ilmu tafsir, fiqh, aqidah-akhlak dan ilmu dakwah. Salah satu kerya yang memuat tentang pentingnya berjuang untuk bangsa dan Negara adalah kiatb Nadzmu Syu'abi al-Iman dan tulisan tentang problematika dakwah islamiyah.

Disisi lain, Kiai Zaini juga aktif melawan penjajah baik melalui organisasi keagamaan maupun melalui jejaring ulama. Hal ini dibuktikan dengan berbagai kesibukan keseharian beliau di sejumlah kegiatan kemasyarakatan dan organisasi keagamaan. Bahkan beliau sempat di penjara di LP Probolinggo karena keberaniaanya menetang penajajah. Belanda sangat menghawatirkan keberadaan Kiai Zaini karena beliau dinggap memiliki pengaruh yang kuat dalam memodilisasi masyarakat untuk melawan Belanda. ${ }^{15}$ Bahkan konon kepergian Kiai Zaini ke tanah Jawa karena menghindar dari kejaran Belanda.

Dalam rangka memperjaungan Islam dan menegakkan kebangsaan dan kenegaraan,

13 Suib, Islam, h. 245-265.

14 M Masyhur, KH Zaini, 167

$15 \mathrm{KH}$. Hefniy Rozak dkk., Profil Singkat dan Riwayat Almarhumin Pondok Pesantren Nurul Jadid, Sekretriat PP. Nurul Jadid, 2016, h. 7. 
$\mathrm{KH}$. Zaini aktif sebagai praktisi organisasi kemasyarakat seperti Nahdhatul Ulama (NU) dengan memangku jabatan selaku Ra'is Syuriyah NU Cabang Kraksaan hingga menjadi wakil Ra'is Pengurus Wilayah (PW) NU Jawa Timur pada tahun 1960. Kiai Zaini juga aktif merintis lembaga pendidikan baik Flour Kelas sebagai jenjang pendidikan lanjutan Madrasah Manhaj al-Nashi'ah al-Islamiyah, Madrasah Mu'allimin pada tahun 1961, Madrasah Tsanawiyah pada tahun 1969. SMP dan SMA Nurul Jadid pada tahun 1970, Sekolah Dasar Islam (SDI) pada tahun 1974 yang dua tahun kemudian berubah menjadi Madrasah Ibtidaiyah Nurul Mukmin. Lembaga Pendidikan Guru Agama Nurul Jadid pada tahun 1974, ADIPNU yang kemudian berubah menjadi PTID dan PTN dan berubah lagi menjadi Institut Agama Islam Nurul Jadid (IAINJ). ${ }^{16}$

Dari paparan di atas menjadi jelas bahwa keislaman dan kebangsaan bagi Kiai Zaini merupakan dua hal yang tidak bisa dipisahkan. Keduanya harus sama-sama diperjuangan demi tegaknya kalimat Allah di bumi nusantara. Keduanya menjadi fokus beliau dalam berjuang semasa hidupnya hingga wafat. Jadi rasa keislaman dan nasionalisme adalah satu kesatuan yang saling menguatkan pada diri beliau demi kemuliaan Islam dan kaum muslimin.

\section{E. Kiprah dan Pemikiran Kebangsaan}

\section{a. Perjuangan Kebangsaan}

Kiai Zaini yang hidup masa pra kemerdekaan hingga pasca kemerdekaan, telah banyak melibatkan dalam perjuangan baik untuk Islam maupun Negara. Untuk mengidentifikasi lebih jauh perjuangan beliau dalam membela agama maupun bangsa setidaknya dapat dilihat dari tiga hal yaitu, melaui jaringan ulama dan itelektual, organisasi dan pesantren. Pada jalur pertama, Kiai Zaini sebagaimana telah disebutkan sebelumnya bahwa beliau memilih hijrah dari Maduran ke Ujung Timur Jawa Timur tepatnya di Situbondo yaitu pesantren Kiai Syamsul Arifin. ${ }^{17}$ Pilihan hijrah ini bukan tanpa asalan,

16 Abd Muqsith Ghazali, “KH. Zaini Mun'im,” dalam Mastuki HS dan M. Isham El-Saha (ed.), Intelektualisme Pesantren Potret Tokoh dan Cakrawala Pemikiran di Era Keemasan Pesantren (Jakarta: Diva Pustaka, 2003), h. 216.

17 Rusydi Sulaiman, Nurul Jadid, Antara Idealisme dan Pragmatisme: Menguak Halikat, Ruh, Tradisi Manajemen akan tetapi untuk mengisolasi diri dari ancaman Belanada bersama teman-temannya untuk mencari tempat dakwah yang lebih aman. Sebelum memutuskan menetap di Probolinggo, Kiai Zaini sempat ingin pindah ke Yogyakarta bersama temannya disana. Kemudian dengan berjalannya waktu beliau memutuskan untuk menetap di desa Tanjung Paiton Probolinggo. Berkat jaringannya di tanah Jawa, Yogyakarta dan daerah lain, Kiai Zaini lebih leluasa berjuang dengan cara yang lebih aman dan efektif hingga akhirnya menetap di Probolinggo. berkat jaringannya yang kuat Kiai sempat keliling di sejumlah Negara-negar Asia dan Eropa; yaitu Singapura, Bangkok, Jepang, Belanda, Jerman, Italy, Prancis, Irak dan Saudi Arabia. Tentu perjalanan tersebut bagi beliau memiliki makna yang kuat guna bekal perjuangan di Indonesia. ${ }^{18}$

Sementara jalur yang kedua adalah melalui organisasi. Organisasi yang menjadi pilihan perjuangan beliau adalah Nahdlatul Ulama (NU). Beliau aktif dibagian syuriah Cabang Kraksaan. ${ }^{19}$ Di NU Kiai Zaini sangat aktif sehingga dikenal di kalangan masyarakat sebagai ulama karikmatik dan diperhitungkan. Bahkan dari cintanya ke NU, pada saaat muktamar NU ke-19 tahun 1952, yang yang memutuskan hasil NU keluar dari Masyumi, Kiai Zaini memutuskan untuk tetap bergabung dan berjuang di NU. Beberapa jabatan yang pernah digeluti beliau di anataranya adalah Rais Syuriah NU Kraksaan, Wakil Rais Syuriah Wilayah Jawa Timur, beliau juga aktif menjadi juru kampanye, asalah satu dewan anggota partai NU perwakilan fungsionaris PBNU wilayah Jawa Timur. ${ }^{20}$

Ketiga, melalui jalur pendidikan pesantren. Jalur perjuangan ini dirinits Kiai Zaini sekiatar tahun 1948 M. Pesantren yang didirkan beliau diberi nama PP. Nurul Jadid, yang berada di Desa Karanganyar Paiton Probolinggo. Saat ini pesantren tersebut sudah memiliki santri sekitar 11.000 orang. Pendidikan yang ada di dalamnya mulai jenjang pendidiakan dasar hingga perguruan tinggi. Di pesantren ini Kiai Zaini banyak mengahsikan waktunya hingga wafat. Di pesantren yang diasuhnya Kiai Zaini banyak

Pondok Pesantren, Madania Center Press, 2020, h. 43

18 Ibid, 42

19 Ibid, 43

20 Matsuki HS, Intelektualisme Pesantren, ........ h. 217, lihat juga, Rusydi Sulaiman, Nurul Jadid.., h. 49. 
manulis, mengajar, dan menuangkan pikiran-pikiran keislaman dan kebangsaanya kepada santri santri masyarakat. Ketiga jalur perjuangan tersebut merupakan media perjuangan Kiai Zaini dalam menuangkan pemikiran, gerakan, gagaran tentang keislaman dan kebangasaan.

Bagi Kiai Zaini berjuang untuk bangsa adalah wajib hukumnya. Makanya tidak heran jika ada dawuh beliau yang sanagt terkenal di kalangan santri yaitu: "Orang yang hidup di Indonesia kemudian dia tidak melakukan perjuangan, maka dia telah berbuat maksiat. Orang yang hanya memikirkan masalah ekonominya saja dan memikirkan pendidikannya sendiri, maka orang itu telah berbuat maksiyat. Kita semua harus memikirkan perjuangan rakyat banyak, bagaimana agar hukum-hukum Allah dalam Al-Qur'an baik yang tersirat maupun tersurat dapat berlaku di bumi Indonesia."21 Beliau selalu mengingatkan kepada para santrinya tentang pentinganya rasa cinta dan berjuang untuk bangsa dan tanah air. ${ }^{22}$ Sebab salah satu cita-cita beliau dalam mendirikan pesantren adalah untuk mencetak kader-kader muslim yang konsekwen. Siap berjuang dimana saja di masyarakat agar masyarakat. Sebagaimana dawuh beliau "Saya membuka pondok ini bukan hanya karena ingin mencetak ulama' (kiai) saja, tapi saya ingin mencetak seorang muslim yang konsekwen. Seorang muslim yang konsekwen adalah disamping selalu memikirkan agama, juga memikirkan kehidupan orang banyak".

Kiai Zaini membangun kesadaran kebangsaan melalui pesantren dan masyarakat. Dalam kesadaran bermasyarakat, santri ditunt menyatu dengan masyarakat, santri harus tampil dengan ilmu yang dimiliki, karena pesantren berada di tengah masyarakat. Sebab masyarakat merupakan pilar utama bagi bangsa dalam menjaga dan menyanggah keutuhan Negara dalam skala ineternasional. Masyarakat merupakan cerminan penting bagi kehidupana bangsa. ${ }^{23}$ Masyarakat dikatakan maju apabila telah tercapai visi dan misi Negara sesuai dengan apa yang dicita-citakan oleh faunding

21 M Masyhur, KH Zaini, h. 74

22 https://www.nuruljadid.net/biografi-kh-zaini-munim, diakses pada tanggal 17 Februari 2021.

23 Suib, Islam, h. 245-265.

Bisri effendi, Pesantren, Globalisasi dan Perjuangan Subaltan, Jurnal An- father yaitu terlepas dari imperialisme dan kolonialisme, makmur sejahtera, bebas dari kemiskinan dan keterbelakangan. ${ }^{24}$ Beliau menyadari bahwa sosok kiai berasal dari komunitas pesantren yang mempersentasikan dari seorang ulama sebagai pewaris para Nabi, berfungsi jihad fisabilillah dengan jalan mengangkat kesejahteraan ummat. ${ }^{25}$ Beliau menyadari bahwa peran pesantren sebagai media dakwah dalam masyarakat adalah bermanfaat dan berkontribusi didalam berjuang jihad fi sabilillah melalui media pesantren.

Melalui pesantren Kiai Zaini mengkader santri yang siap berjuang untuk agama dan bangsa (centre of excellent), mencetak sumber daya manusia dan melakukan pemberdayaan masyarakat. Selain sebagai pengasuh, Kiai Zaini juga pernah menajdi Direktur Perguruan Tinggi Ilmu Dakwah Nurul Jadid (PTID) (sekelas Rektor kalau masa sekarang). Pada acara wisuda mahasiswa beliau membacakan Dies Riede Natalis ke III perguruan tinggi yang dipimpinnya tersebut. Dies Riede tersebut berjudul "Beberapa problematika dakwah Islamiyyah". Judul ini diambil dari firman Allah SWT: Artinya: maka gembirakanlah kepada hamba-hambaku yang mendengarkan perkataan, lalu mengikuti apa yang terbaik diantaranya, mereka itulah orang-orang yng telah diberi petunjuk oleh Allah dan mereka itulah orang-orang yang mempunyai akal. QS: Al-Zumar ; 18) ${ }^{\mathbf{2 6}}$

Dari sudut pembangunan bangsa, beliau menghendaki agar membangun dalam semua aspek kehidupan sesuai dengan ajaran agama dengan menggunakan ilmu pengetahuan, tetap mempertahankan kepribadian dan kebudayaan ummat. ${ }^{27} \mathrm{Hal}$ ini sejalan dengan karya beliau dalam kitab Syuabul Iman, yang berbunyi wajib bagi manusia memiliki kemampuan iman yang benar, mencari keteguhan hati, dengan pikiran, ilmu dan itjihad, dalam memperoleh kesempurnaan melalui amal dan ahwal yang shaleh. ${ }^{28}$ sementara cabang iman yang keduapuluh satu adalah adalah rasa kasih sayang dalam hari seseorang kepada semua makhluk, wajib

24 Yanto Bashri dan Retno Suffatni, Sejarah Tokoh Bangsa, 2012, LKiS Printing, Yogyakarta, 10

25 H A Jazuli, Kaidah-kaidah Fikih, Kaidah-kaidah Hukum Islam dalam Menyelesaikan masalahmasalah yang Praktis, 2011, Jakarta, Kencana Prenada Media Group, h. 147

26 Alquran: Al-Zumar: h. 18.

27 M Masyhur, KH Zaini, h. 168

28 Ibid., h. 4. 
bagi orang mukmin menyayangi sesama sebagaimana Allah menyayangi makhlunya. ${ }^{29}$

\section{b. Al-wa'y al-hukumi wa al-sya'bi>: Refleksi Pemikiran Kebangsaan dan Islam Wasathiyah}

Kiai Zaini selaku ulama' Nusantara, jauh sebelum mendirikan pesantren telah membuktikan secara nyata kiprah dan perjuangannya dalam membela kemerdekaan. Keteguhannya dalam membela bangsa pada akhirnya harus menunut beliau eksodus (hijrah) dari Madura ke daerah yang lebih kondusif bersama koleganya, yaitu Situbondo Jawa Timur, hingga akhirnya memilih menatap di Probolinggo. selama di Probolinggo beliau masih dikejar oleh pihak Belanda hingga dipenjara di LP Probolinggo. Keberpihakannya kepada hak-hak raykat banyak memuat piahak Penjajah khawatir sehingga selalu membuntuti pergerakan Kiai Zaini. Karena ia teguh dalam bersikap dan memperjuangkan hak-hak rakyat. Kiai Zaini dikenal cukup berani dalam membela kebenaran.

Selain gerakan nyata dalam bentuk tindakan, yang tidak kalah pentingnya adalah pemikiran Kiai Zaini tentang pentingnya membela bangsa dan Negara melalui pemikiran kebangsaannya. Untuk mengetahui pemikiran kebangsaan dan kenegaraan Kiai Zaini, kita dapat menelisik dari Qanun Asasi PP. Nurul Jadid, pasa 6 ayat 1 dan 2. Pada pasal 6 ayat 1 berbunyi Nilai-nilai Pondok Pesantren Nurul Jadid terdiri dari nilai kesadaran dan nilai mawas diri. Sedangkan pada pasal 6 ayat 1 berbnyi: Nilai kesadaran berwujud Panca Kesadarasan Santri meliputi: kesaran beragama, kesadaran berilmu, kesadaran bermasyarakat, kesadaran berbangsa dan bernegara dan kesadaran berorganisasi. ${ }^{30}$ Lima nilai kesadaran santri yang dicetuskan Kiai Zaini terebut lahir dari pemikiran-pemikiran beliau dalam sejumlah karyanya, dan nasihat-nasihat yang pernah disampaikan kepada para santri dan masyarakat. ${ }^{31}$

Dari kelima nilai kesadaran di atas, nilai kesadaran berbangsa dan bernegara secara spesifik tercantum pada nilai yang nomor lima, yang dikenal dengan "al wa'y al-

29 Ibid.,h. 13.

30 Qanun Asasi PP. Nurul Jadid 2018, lihat juga Suib, Islam..., h. 6.

31 Suib, Islam, h. 6 hukumi > wa al-sya'bi (kesadaran berbangsa dan bernegara)>". Pemikiran ini membuktikan bahwa Kiai Zaini tidak membenturkan antara kebangsaan dan kenegaraan dengan keislaman, bahkan kesadaran perjuangan keagamaan inhern dengan kesadaran berbansga. Artinya memperjuangkan nilainilai kebangsaan dan keislaman dengan menjaga keutuhan bangsa adalah bagian dari perjuangan keislaman. Sebab Islam sendiri sebagai agama tidak akan berjalan dengan baik tanpa adanya dukungan Negara. Oleh karenannya mempertahankan keutuhan dan kemerdekaan bangsa dan Negara menjadi wajib hukumnya bagi setiap orang Islam sebagai bentuk perjuangan untuk menegakkan kalimat Allah (Islam). Karena keberlangsungan ajaran Islam membutuhkan keberlangsungan dan keutuhan Negara.

Kesadaran berbangsa dan bernegara yang diposisikan sebagai kesadaran keempat dalam Panca Kesadaran Santri, ${ }^{32}$ dimaksudkan bahwa santri harus memiliki pandangan, dan sikap atau wawasan, serta tanggungjawab dalam pembangunan bangsa dan negara, sebagai bagian dari tugas keagamaan. Sikap nasionalisme dan patriotisme, merupakan bagian penting dari jiwa kesantrian, sebagai bentuk tanggungjawab terhadap kelangsungan hidup bangsa dan Negara Kesatuan Republik Indonesia. Pengalaman Kiai Zaini yang terlibat langsung dalam perjuangan kemerdekaan Republik Indonesia, tentu ikut menginspirasi dalam perumusan kesadaran berbangsa dan bernegara, karena itu pula beliau senantiasa menyampaikan bahwa satri Nurul Jadid harus menjadi muslim aktif, harus berjuang di masyarakat untuk agama, bangsa dan negara, sesuai dengan bakat dan keahlian serta profesinya masing-masing. ${ }^{33}$

Pemikiran Kiai Zaini di atas terkonfirmasi dari berbera pernyataan beliau baik saat pengajian atau percakapan. Salah satu pernyatan Kiai Zaini yang cukup mashur di kalangan santri Nurul Jadid yaitu: "Barang siapa yang tinggal di Indonesia, kemudian

32 Profil PP Nurul Jadid. h.43

$33 \mathrm{KH}$. Hefni Razaq dkk (Tim Penyusun), Profil Pondok Pesantren 32-35, eksistensi pesantren membentengi paham radikalisme agama: "panca kesadaran santri" pemikiran KH. Zaini mun"im Nurul Azizeh Mahasiswi Pendidikan Agama Islam Universitas Nurul Jadid, Proceeding, Converence of Islamic Civilization Islamic Values in Facing Globalization, Univercity of Darussalam Gontor, 15-16 Sepetmeber 2018, ISBN, 7898-602 5620-14-0, h, 280. Lihat juga hasil , Wawancara, Aqiq Zaman, 
dia tidak berjuang untuk kepentingan orang banyak, hanya memikirkan kepentingan dirinya sendiri maka ia telah bermaksiat." 34 Dari perkataan tersebut dapat dipahami bahwa beliau punya sikap yang tegas terkait pentingnya perjuangan termasuk perjuangan dalam membela Negara. Bahkan orang yang tidak berjuang untuk kepentingan orang banyak dianggap telah melakukan pelanggaran agama (maksiat). Artinya santri yang sudah kembali ke masyarakat tidak boleh berpangku tangan, atau hanya memikirkan kepentingannya sendiri. Akan tetapi santri harus ikut andil dalam berdakwah dan perjuangan masyarakat.

Dalam pernyataan Kiai Zaini versi lain yang juga mashur di kalangan santri adalah: Saya tidak ridla jika santri saya setelah pulang ke masyarakat tidak berjuang untuk kepentingan orang banyak. ${ }^{35}$ Pernyataan ini cukup keras nadanya ketimbang pernyataan sebelumnya. Kiai Zaini tidak hanya menganjurkan perjuangan, tapi ridla melihat santrinya yang sudah kembali ke masyarakat tidak memikirkan kepentingan umat. Atrinya, Kiai Zaini mencetak santri Nurul Jadid agar memiliki jiwa perjuangan, tidak hanya berpangu tangan hanya memilikirkan karirnya sendiri, ekomoni dan pendidikannya sendiri. Santri harus ambil bagian dalam perjuangan baik untuk kepentingan agama, masyarakat, bangsa dan Negara. Santri ambil bagian dalam perjuangan sesuai dengan kamampuan, kompetensi dan keahliannya masing-masing. Tidak harus jadi kiai semua, tapi menjadi apa saja yang penting berjuang untuk kemanfaatan dan kemaslahatan orang banyak. Misalnya jika tidak mampu menjadi guru, ya bisa membantu pembangunan samara pendidikan dan ibadah, sebagaimana diungkapkan $\mathrm{H}$. Luthfi santri mengatakan bahwa perjuangan itu tidak harus sama misalnya jadi kiai semua, tapi bisa menjadi pebisnis yang bisa berjuangan lewat harta dan kekayaanya. ${ }^{36}$

Perkataan tersebut menunjukkan bahwa kiai Zaini menginginkan para santrinya

34 Perkataan Kiai Zaini tersebut telah masyhur di kalangan santri Nurul Jadid, petikan kalimat tersebut juga didapat dari hasil wawancara dengan Dr. Akik Zaman, H. Faizin Samweil dan KH. Pada tahun 2020.

35 Penyampaian Dr. Adam pada acara haul dan Harlah Nurul Jadid pada tanggal 13 Maret 2021 di PP. Nurul Jadid.

36 H. Luthfi Adzim, Wawancara, Probolinggo, 14 Maret 2021. Dia alumni PP. Nurul Jadid tahun 80 an, menyaksikan langsung Kiai Zaini sekitar dua tahun sebelum Kiai dipanggil Allah SWT. . saat kembali ke masyarakat tidak hanya berpangku tangan, memikirkan dirinya sendiri seperti memikirkan kepentingan ekonomi dan pendidikannya sendiri. Akan tetapi beliau menginginkan agar santrisantrinya ikut andil dan ambil bagian dalam memperjuangkan kepentingan agama, bangsa dan Negara. Dua perkataan beliau di atas bagi kalangan santri tidak hanya berupa anjuran, tapi perintah yang wajib hukumnya untuk mematuhinya. Ia juga menjadi doktrin penting dalam pembentukan karakter santri sehingga memiliki jiwa juang dan militansi dalam memperjuangan kepentingan umat termasuk kepentingan bangsa dan Negara.

Dapat dipahami bahwa pemikiran keislaman Kiai Zaini tidak bertentangan dengan paham kebangsaan. Bahkan keduanya saling mendukung untuk kemajuan Islam itu sendiri. Oleh karenya wajar jika di kalangan nahdliyyin ada adegium cinta tanah air sebagian dari iman. Sebab sejatinya Pesantren pada awalnya merupakan pusat pengembangan nilai-nilai dan penyiaran agama Islam. ${ }^{37}$ Namun dalam perkembangannya pondok pesantren bukan hanya aspek spiritual, akan tetapi memperlebar kepada akses pada aspek politik, sosial dan pemberdayaan ekonomi masyarakat.

Pemikiran Kiai Zaini tentang kebangsaan ini juga secara tegas tercantum dalam kitab Nasdam Syuabul Iman,yang dijelaskan pada cabang Iman yang ke 57, yaitu jihad untuk menjaga keamanan umat dan Negeri. Dalam kitab tersebut Kiai Zaini membagi jihad disini mejadi dua bagian, yaitu jihad dalam makna perang dan jihad dalam arti dakwah. ${ }^{38}$ Dalam Islam jihad makna pertama dilakukan sebagai bentuk pertahanan dan pemebelaan bukan penyerangan. Jihad hanya mungkin dilakukan jika ada musuh yang menyerang. Jihad diarahkan guna mencapai keamanan warga umat dan Negara. Seandainya ada sebagian golongan umat yang menolak perjuangan, niscaya pertahanan para tokoh agama, tempat ibadah seprti masjid menjadi runtuh, yang mana para agamwan dan tempat ibadah adalah tempat tegaknya tanda-tanda agama. Oleh karenanya Kiai Zaini menghimbau agar kita mempersiapkan sumber daya untuk mempertahankan kekuatan bangsa melalui

37 Suib, Islam, h. 245-265.

38 Syekh Zaini Mun'im, Nadzam Syuabul Iman, Nurul Jadid, h. 21 
kekuatan tentara dan senjata yang memadai. Selain dengan kekuatan senjata dan tentara adalah kekuaran ilmu dan hujjah serta ulama. Tujuan dakwah tersebut guna tegaknya agama Islam. ${ }^{39}$

Sementara jihad dalam makna yang kedua adalah dakwah dalam bentuk ajakan kepada manusia agar menyembah Allah dan menjalahkan perintah agama. Dakwah ini dilakukan dengan cara hikmah, memberi peringatan yang baik dan jika diperlukan dengan cara berdebat yang beradab dan santun. ${ }^{40}$ Pemikiran kiai Zaini ini sejalan dengan ayat Alquran Surat An Nahl ayat 125.41 Sebab untuk menegakkan ajaran agama memerlukan sebauah Negara-bangsa yang aman, oleh karenanya berjuang demi keamanan bangsa dan Negara menjadi wajid sebab ia menjadi prasyarat terpenuhinya pekerjaan wajib. Oleh karenanya memenuhi prasayrat yang mendukung terpenuhinya perkara wajib juga wajib hukumnya dipenuhi. Misalnya wudlu yang mana hukum asalanya adalah sunnah, akan tetapi shalat yang hukum wajib tidak sah jika tidak punya wudlu. Oleh karenanya wudlu menjadi wajib saat dibutuhkan untuk melaksakanan shalat. Demikian juga agama, ajaran Islam tidak dapat berjalan dengan sempurna seperti kewajiban melaksanakan ibadah haji tanpa dukungan dan keutuhan Negara. Artinya mau tidak mau Negara menjadi prasayarat terlaksananya ajaran Islam.

Jadi, secara prinsip pemikiran Kiai Zaini tentang perlunya berjuang untuk bangsa dan Negara adalah menjadi tujuan antara, yang tujuan akhirnya adalah tegaknya agama Islam dan kaum muslimin. ${ }^{42}$ Namun tegaknya Islam dan kaum muslimin memerlukan wadah yang damai yaitu Negara. Oleh karenanya memperjuangkan kedamaian dan kemakmuran Negara menjadi hukumnya sebab tanpanya, ajaran Islam tidak bisa dijalankan dengan baik. Jika kita kolaborikan

39 Ibid, h. 21

40 Syekh Zaini Mun'im, Nadzam ..., h. 21

41 Surat An Nahl ayat 125:

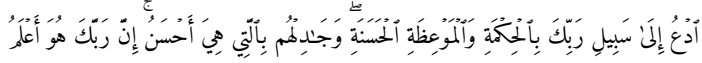

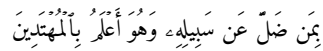

Artinya: "Ajaklah (manusia) ke jalan Tuhanmu dengan hikmah dan pengajaran yang baik dan bantahlah mereka dengan cara yang lebih baik. Sesungguhnya Tuhanmu lebih mengetahui siapa yang sesat dari jalannya dan Dia lebih mengetahui orang - orang yang mendapat petunjuk"

42 Syekh Zaini Mun'im, Nadzam.., h. 22 antara "al-wa'y al hamsah" sebagai ideologi pesantren Nurul Jadid dengan pemikiran Kiai Zaini dalam kitab Syuabul Iman merupakan komitmen keislaman, kebangsaan dan kenegaraaan. Antara keislaman dan kebansgaan berjalan beriringan, tanpa mengorbankan salah-satunya. Artinya kesadaran yang ingin dibangun Kiai Zaini sebenarnya adalah kesadaran perjuagan (al-ruh al-jiha $>d$ ) kebangsaan yang diilhami kesadaran agama, dan ilmu.

Dengan membaca pemikiran kebangsaan Kiai Zaini di atas maka menjadi jelas bahwa Islam pesantren tidak mungkin tidak menghendaki Islam Vs Negara. Artinya gerakan radikalisme yang belakangan bermunculan mengatasnakan agama sama sekali tidak sejalan dengan pemikiran pesantren. Oleh karenanya pesantren tidak tidak mempermasalahkan bentuk Negara, apakah ia harus Islam dan tidak. Terhadap bentuk Negara demokrasi pancasila, Kiai Zaini tidak mempermaslahkan selagi umat Islam dapat menjalankan ajaran agamanya. Ada dua macam menurut beliau materi masyru' (disyariatkan) seperti aqidah, ibadah dan tata tertib masyarakat. Kedua ma'ruf artinya semua perbuatan yang bermanfaat dan dipandang baik, namun tidak menyalahi ajaran-ajaran Islam, kebalikan dari munkar. ${ }^{43}$

Sementara dalam pengembangan nilai-nilai kebangsaan yang terapkan di pesantren oleh Kiai Zaini, antara lain dengan mengembangkan sikap moderat dalam menghadapi realitas pluralitas umat Islam dan bangsa Indonesia. Bagi Kiai Zaini perbedaan itu suatu keniscayaan, karena itu dalam pembangunan kehidupan berbangsa tidak perlu mempersoalkan perbedaan-perbedaan yang ada, melainkan harus lebih diarahkan untuk mencari titik temu atau persamaanpersamaannya, sehingga persatuan dan kesatuan bangsa semakin kokoh. ${ }^{44}$ Pernah Kiai Zaini marah ketika perselisihan yang ada di antara NU dan Muhammadiyah terus dipertajam bahkan beliau enggan jika umat dikotak-kotakan atau dibeda-bedakan. Kiai zaini tidak hanya memikirkan soal agama saja tapi juga masalah kebangsaan dan kenegaraan, seperti yang tercermin dalam fatwa beliau: Orang yang hidup di Indonesia kemudian tidak melakukan perjuangan, dia

43 M Masyhur, KH Zaini, h. 169

44 M. Masyhur Amin, M Nasikh Ridwan, KH. Zaini Mun'im......., h. 73 
telah berbuat maksiat. Orang yang hanya memikirkan masalah ekonominya saja dan pendidikannya sendiri, maka orang itu telah berbuat maksiat. Kita semua harus memikirkan perjuangan rakyat banyak, bagaimana agar hukum-hukum Allah yang ada dalam Al-Quran baik yang tersirat maupun yang tersurat dapat berlaku di bumi Indonesia. 45

Maka menjadi sebuah keniscayaan jika di kalangan pesantren ada adegium "cinta tanah air adalah bagian dari pada iman". Artinya membela bangsa dan Negara secara tidak langsung juga berjuang untuk Islam. Semangat ini yang harus dimiliki para santri agar rasa memiliki dan bertanggung jawab terhadap maju mundurnya suatu bangsa. Dalam konteks ini ulama pesantren menolak secara tegas paham Wahabi yang mementingkan pan Islamisme, uniformitas, dan dalam batasbatas tertentu mirip dengan globalisasi. ${ }^{46}$ Karena gerakan tersebut lebih mengedepankan simbol dari pada substansi Islam itus sendiri. Dari kesadaran berbangsa dan bernegara ini beliau juga sebagai motivator, pendorong pada front Pancasila dalam menggerakkan ruh perjuangan membela Pancasila dari ancaman komunis beserta antek-anteknya. ${ }^{47}$

\section{F. Penutup}

Pemikiran kebangsaan Kiai Zaini yang tertuang dalam panca kesadaran santri yaitu kesadaran berbangsa dan bernegara adalah pilihan sikap yang dan refleksi dari ideologi dan pemikiran keislaman belaiu. Kiai Zaini tidak mempertengkan antara Islam dengan kebangsaan. Islam dan kebangsaan tidak perlu dipertentangkan secara vis a vis. Tapi keduanya saling mengisi sebab tegaknya Islam membutuhnkan tegaknya sebuah bangsa dan Negara. Demikian pula sebaliknya, tegaknya sebuah bangsa dan Negara memerlukan kokohnya dan eksistensi nilai-nilai agama. Namun memperjuangan ketahanan bangsa dan Negara menurut beliau mesti dijiwai dengan kesadaran agama dan kesadaran berilmu dalam kerangka mempertahankan tegaknya Islam. Artinya gerakan apapun yang mengancam keutuhan berbangsa dan bernegara dalam bentuk apapun

\footnotetext{
45 Arsip wawancara dengan $\mathrm{KH}$. Hasan abdul Wafi, menantu KH. Zaini Mun'im, h. 281

46 Bisri effendi, Pesantren, Globalisasi Dan Perjuangan Subaltan, Jurnal An-Nufus, Vol.4 No.2 Nopember 2005

47 M Masyhur, KH Zaini, h. 89.
}

seperti gerakan ektremisme dan radikalisme atas nama agama tidaklah dibenarkan. Pemikiran kebangsaan Kiai Zaini sejalan dengan pemikiran tasawwufnya Imam Al-Ghazali yang menegaskan bahwa agama dan negara tidak bisa dipisahkan. Kiai Zaini menolak konsep Negara Sekuler. Agama tanpa adanya Negara akan sirna, karena Negara adalah tempat berpijak (tanah air) untuk meneggakan Agama. Begitu juga Negara tanpa Agama juga akan runtuh, karena Agama merupakan ruh dari sebuah tatanan Negara. Walhasil, Kiai Zaini bertujuan untuk menjaga nilai-nilai syariat Islam yang terkandung dalam Maqashid Syariah melalui tatanan bangsa negara.

\section{Daftar Pustaka}

Al-Ghazali, Imam. Bidayatul hidayah,tt

Amin, M Masyhur. \& Ridwan, M Nasikh. KH Zaini Mun'im (Pengabdian dan Karya Tulisnya), Yogyakarta, LKPSM, 1996.

Bashri, Yanto. \& Suffatni, Retno, Sejarah Tokoh Bangsa, Yogyakarta, LKiS Printing, 2012

Al-Ghazali, Imam. Bidayatul hidayah,tt

Chodjim, Achmad. Sunan Kalijogo Mistik Dan Makrifat, Jakarta, Serambi Ilmu Semesta, 2013

Effendi, Bisri. Pesantren, Globalisasi dan Perjuangan Subaltan, Jurnal an- Nufus, Vol.4 No.2 Nopember 2005

Greg Barton, Biografi Gusdur, The Authorized Biography of Abdurrahman Wahid, Yogyakarta, LKis, 2010

Harits, Busyairi, KH A, Islam Nu (Pengawal Tradisi Sunni Indonesia), Surabaya, Khalista, 2010.

Iqbla, Muhammad. \& Nasution, Husein, Amin. Pemikiran Politik Islam Dari Masa Klasik Hingga Indonesia Kontemporer, Jakarta, Kencana Prenada Media Group

Jazuli, H A. Kaidah-Kaidah Fikih, Kaidah-Kaidah Hukum Islam Dalam Menyelesaikan Masalah-Masalah Yang Praktis, Jakarta, Kencana Prenada Media Group, 2011

M Jadul Maula, Kembali ke Khittoh 1945, Negara Republik Indonesia adalah negara Islam nya ummat Islam Indonesia menurut Nahdhotul Ulama', dalam Khittoh dan khidmah NU, Majma' Buhuts an-Nahdiyyah, 2014, Pati, Jawa Tengah

Muhammad Fu'ad abdul Baqi'. Mutiara Hadits Yang Disepakati Bukhori Dan Muslim, (Lu'luwal Marjan), Surabaya, Bina Ilmu,

Nawawi, Ismail, Metode Penelitian Kualitatif, 
Sidoarjo, Dwiputra Pustaka Jaya, 2012

Pranowo, M. Bambang. Memahami Islam Jawa, Jakarata, Alvabet, Profil PP Nurul Jadid.

Sekh Zaini Abdul Mun'im, Nadham su'abul iman, t.th.

Suib, M. Syaiful. "Islam dan Indonesia Menurut KH Zaini Mun'im: Wawasan Tentang Islam Nusantara." AT-TURAS: Jurnal Studi Keislaman 5.2 (2018): 245-265.

Sundusiyah, Sundusiyah. KH. Zaini Mun'im: seorang figur ulama, pendidik dan politikus. Diss. IAIN Sunan Ampel Surabaya, 1995.

Mun'im, A. Rafiq Zainul. "Konsep Mukmin dalam Tafsir Al-Qur'an Bi Al-Imla'Karya KH. Zaini Mun'im." (2017): 18-31.
Wijaya, Askin. Menusantarakan Islam, Jakarta, Nadi Pustaka, 2012

Yatim, Badri. Sejarah Peradaban Islam, Jakarta, Rajagrafindo, 2008

Wawancara, Dr. H. Aqiq Zaman, Situbondo, 2020

Wawancara, H. Faizin Samwil, Probolinggo, 2020

Wawancara, Drs. H. Luthfi Adzim, Probolinggo, 2020

Wawancara, KH. Mursyid, Bindowoso, 2020

Wawancara, K. Hilmi, Bawean, 2021 